Original Article

\title{
Combining Ability of Agronomic Traits in Sunflower (Helianthus annuus L.) Through Line x Tester
}

\author{
Attia M. A. ${ }^{1}$, Bakheit B. R. ${ }^{2}$, Abo-Elwafa A. ${ }^{2}$ and El-Shimy A. A. ${ }^{1}$ \\ ${ }^{1}$ Department of Oil Crops Research, Field Crops Research Institute. Agriculture Research Centre, Egypt. \\ ${ }^{2}$ Agronomy Department, Faculty of Agriculture, Assiut University, Assiut, Egypt.
}

doi:

\section{Abstract}

Twenty three inbred lines (selfed) were top-crossed with two testers. The 46 top crosses along with their parents were planted in Randomized Complete Block Design (RCBD) with three replications. The results showed highly significant mean square of crosses was observed for all the traits including days to $50 \%$ flowering, days to maturity, plant height, stalk diameter, head diameter, 100-achene weight, achene yield/plant, achene yield/plot and oil content, indicating significant variation for these traits. The mean squares due to lines were highly significant. While, variance among testers were highly significant only for plant height, head diameter and oil content. The results revealed that ten $\mathrm{S} 1$ lines $\left(\mathrm{S}_{1}, \mathrm{~S}_{3}, \mathrm{~S}_{5}, \mathrm{~S}_{7}, \mathrm{~S}_{8}\right.$, $\mathrm{S}_{11}, \mathrm{~S}_{13}, \mathrm{~S}_{15}, \mathrm{~S}_{17}$ and $\mathrm{S}_{23}$ ) exhibited positive GCA effects. Nine lines out of ten were significant or highly significant GCA effects. These lines should be considered as good combiners for oil content, and its implies that these lines possess favorable alleles with additive genetic effects for this trait.

KEYWORDS

Sunflower,

Helianthus annuus,

GCA,

SCA,

Inbred lines,

line $\mathbf{x}$ tester

CORRESPONDING

AUTHOR

Mahrous A. Attia

mahrous.baset@yahoo.com

The same result was found by the analysis of half-sib families. Whereas, that the respective $S_{1}$ lines would have good g.c.a for oil content and selected as parent to produce the first cycle of recurrent selection for the population H.S. Concerning the SCA values for oil content, the results indicated that thirteen crosses were positive and significant or highly significant. These crosses were suitable combination and can be superior candidate for improving high oil content genotypes. Therefore, we are selected the best 10 crosses exhibited positive significant or highly significant, $\left(\mathrm{S}_{1} \times \mathrm{A}_{21}, \mathrm{~S}_{3} \times \mathrm{A}_{3}, \mathrm{~S}_{4} \times \mathrm{A}_{3}, \mathrm{~S}_{5} \times \mathrm{A}_{21}, \mathrm{~S}_{8} \times \mathrm{A}_{3}, \mathrm{~S}_{14} \times \mathrm{A}_{21}, \mathrm{~S}_{15} \times \mathrm{A}_{21}\right.$, $\mathrm{S}_{17} \times \mathrm{A}_{3}, \mathrm{~S}_{20} \times \mathrm{A}_{3}$ and $\mathrm{S}_{23} \times \mathrm{A}_{21}$ ) as parents to produce the first cycle of recurrent selection for population top crosses.

\section{INTRODUCTION}

Sunflower (Helianthus annuus L.) is one of the most important oilseed crops in the world. Selection for high oil in Russia began in 1860 and was largely responsible for increasing oil content from $28 \%$ to almost $50 \%$. The cultivated area in the world was 24.80 million hectares producing 37.45 million ton with an average 1.51 ton/ha. In Egypt the cultivated area was 8 thousand hectares producing 20 thousand tons with an average 2.50 ton/ha (F. A. O, 2011).
The line $\times$ tester analysis one of the efficient methods of evaluating a large number of inbred as well as providing information on the relative importance of general and specific combining ability effects for interpreting the genetic basis of important plant traits. Recently, line $\times$ tester analysis has widely been used for combining ability tests as reported by (Singh and Chaudhary 2001). Khan et al. (2008) evaluated eight sunflower parents and their sixteen F1 hybrids to estimate mid and high parent heterosis for seed yield and oil 
content. Highly significant genetic differences $(\mathrm{P}<0.01)$ were observed among parents and $\mathrm{F} 1$ hybrids for yield/hectare, harvest index, moisture factor and oil content. Mid parent and high parent heterosis estimates of F1 hybrids ranged from 5.60 to $185.02 \%$ and -9.06 to $181.73 \%$ for yield/hectare, 23.33 to $171.66 \%$ and -43.91 to $127.36 \%$ for harvest index, 11.19 to -30.35 and 19.13 to -20.71 $\%$ for moisture factor and -4.78 to $52.85 \%$ and -18.39 to $42.50 \%$ for oil content, respectively.

Bakheit et al. (2010) showed that the differences among genotypes were highly significant for all studied traits. The interaction among genotypes and years was highly significant for all studied traits. Also, highly significant differences were detected among parents, crosses, their partitions; lines (females), testers (males) and lines $\times$ testers and parent vs. crosses for all studied traits. The earliest cross over the two seasons was (L5 $\times$ Rf10). The cross $($ L19 $\times$ Rf4) had the broadest head in both seasons and at the combined level over the two years. All crosses had broadest head diameter than the check variety Giza 102.

Soheila et al. (2013) found that crosses of RGK$21 \times$ AGK-52, RGK-19 $\times$ AGK-52 and RGK-21 $\times$ AGK-148 were identified with desired specific combining ability (SCA) for grain and oil yield. It is concluded that selection for achieving high grain yield must be done for grain/head and 1000-kernel weight. The objective of this research was to estimate general and specific combining ability effects to identify the parental lines of the best crosses.

\section{MATERIALS AND METHODS}

Twenty three inbred lines (selfed) were topcrossed with two testers $\left(A_{3}\right.$ and $\left.A_{21}\right)$ cytoplasmic male sterile lines at Shandaweel Agriculture. Research Station, Agri. Res. Center in 2010 summer season, for characterization and produced forty six top crosses. In 2011 season, the twentythree $S_{1}$ per se lines, the 46 top-crosses and the two testers $\left(\mathrm{B}_{3}\right.$ and $\left.\mathrm{B}_{21}\right)$ were planted at Shandaweel Agric. Res. Station. The Randomized Complete Block Design (RCBD) with three replications was used; the plot size was 1 rows, 4 meter long and 60 $\mathrm{cm}$ apart. Planting was done in hills spaced $25 \mathrm{~cm}$ apart. Seedlings were thinned to one plant per hill before the first irrigation (two weeks after planting). The cultural practices followed the recommendation for oil seed sunflower production. At harvest, the oil percentage was determined in the all genotypes.

\section{The studied characters}

The traits studied in this study could be divided into three sub headings such as earliness, growth traits and yield components.

\section{A. Earliness traits}

1. Days to $50 \%$ flowering: number of days from sowing date to appearance of heads $50 \%$ of plants.

2. Days to maturity: was measured as number of days from sowing date until the head became yellow on plot basis.

\section{B. Growth traits}

The following traits were taken from random sample of five guarded plants. These plants were chosen from each plot and assigned to be fixed for the following measurements.

1. Plant height, $\mathrm{cm}$ : average length in $\mathrm{cm}$ from soil level to the tip of the head.

2. Stalk diameter, $\mathrm{cm}$ : measured at $30 \mathrm{~cm}$ above the soil surface with vernier-calipers, at nearest $0.1 \mathrm{~cm}$.

3. Head diameter, cm: estimated as an average of maximum width of the head.

\section{Yield and yield components}

1. Achene yield/plant, g: estimated as average of seed weight/head.

2. Achene yield/plot, g: measured from the adjusted seed yield/plot. 
3. 100-achene weight, g: One hundred seed were counted and weighed from the bulk of the guarded plants in grams.

4. Oil content: random sample of seeds were taken from the seed yield of the five guarded plants. The oil content was determined by soxalet apparatus using petroleum ether $\left(\mathrm{Bp} 40-60 \mathrm{c}^{\mathrm{o}}\right)$ as solvent according to the official method (A. O. A. C. 1980).

\section{Statistical analysis}

The analysis of variance by using line $\mathrm{x}$ tester analysis was calculated according to Kempthorne (1957). The sum of squares for the F1 top crosses was partitioned components due to testers (T), lines (L) and line $\mathrm{x}$ tester interaction.

\section{Estimation of variance components}

Mean squares were equated to obtain estimates of the components of variance for lines $\left(\sigma^{2} l\right)$, testers $\left(\sigma^{2} t\right)$ and lines $x$ testers $\left(\sigma^{2} l \times t\right)$ in Table (1).

$$
\begin{gathered}
\delta^{2}{ }_{l}=\frac{M_{1}-M_{3}}{r t} \\
\delta^{2}{ }_{t}=\frac{M_{2}-M_{3}}{r l} \\
\delta^{2}{ }_{l t}=\frac{M_{3}-M_{4}}{r}
\end{gathered}
$$

Where:

$\sigma^{2} l=\operatorname{cov}$. Between maternal half sibs $=\sigma^{2}$ GCA (l)

$\sigma^{2} \mathrm{t}=$ cov. Between parental half sibs $=\sigma^{2}$ GCA $(\mathrm{t})$

$\sigma^{2} 1 \times t=$ cov. Full sib -2 cov. Half sib $=\sigma^{2}$ SCA

General combining ability (GCA) effects for the parents and testers and specific combining ability (SCA) effects of the crosses were estimated according to Singh and Chaudhray (1977). The model used to estimate GCA (additive) and SCA (non additive) effects of the Xijk th observation was:

$$
X_{i j k}=\mu+g_{i}+g_{j}+S_{i j}+e i_{j k}
$$

Where:

$\mu=$ overall population mean.

gi $=$ GCA effect of the ith female parent.

gj $=$ GCA effect of the ith male parent.

$\mathrm{Sij}=$ SCA effects of the ith cross combination.

eijk $=$ The error associated with the xijk observation.

$\mathrm{i}=$ number of male parents $=1,2, \ldots, \mathrm{m}$.

Estimation of general combining ability (GCA) effects

General combining ability (GCA) from lines

$$
\text { g.c.al }=\frac{x i . .}{t r}-\frac{x \ldots}{l t r}
$$

Where:

$\mathrm{t}=$ No. of testers (males).

$1=$ No. of lines (females).

$r=$ No. of replications.

General combining ability (GCA) from testers

$$
\text { g.c.at }=\frac{x . j .}{l r}-\frac{x . . .}{l t r}
$$

\section{Estimation of the specific combining ability (SCA) effects}

$$
S i j=\frac{x i j .}{r}-\frac{x i . .}{r t}-\frac{x . j .}{r l}+\frac{x \ldots}{r l t}
$$

Where:

$\mathrm{xij}=$ total of the $1 \mathrm{t}$ th top cross over all replications.

\section{Estimation of standard error for combining ability effects}

S.E $\left[\right.$ GCA for lines] $=(\mathrm{Me} / \mathrm{rt})^{1 / 2}$

S.E $\left[\right.$ GCA for testers] $=(\mathrm{Me} / \mathrm{rl})^{1 / 2}$

S.E $[$ SCA effects $]=(\mathrm{Me} / \mathrm{r})^{1 / 2}$

Where:

$\mathrm{Me}=$ mean square for error (error variance) gi, gj and sij are general combining ability for line i, line $\mathrm{j}$ and specific combining ability for cross ij respectively. 
Table (1) Portion of the separate ANOVA showing the partitioning of sum of squares for F1 top crosses and expectations of mean squares.

\begin{tabular}{|l|c|c|c|}
\hline $\begin{array}{l}\text { Source of } \\
\text { variance }\end{array}$ & D. F & $\begin{array}{c}\text { Mean } \\
\text { squares }\end{array}$ & $\begin{array}{c}\text { Expectation of } \\
\text { mean square }\end{array}$ \\
\hline $\begin{array}{l}\mathrm{F}_{1} \text { top } \\
\text { crosses }\end{array}$ & $(\mathrm{lt}-1)$ & & \\
\hline Line (L) & $(1-1)$ & $\mathrm{M} 1$ & $\sigma^{2}+\mathrm{r} \sigma^{2} \mathrm{lt}+\mathrm{rt} \sigma^{2} 1$ \\
\hline Tester (T) & $(\mathrm{t}-1)$ & $\mathrm{M} 2$ & $\sigma^{2}+\mathrm{r} \sigma^{2} \mathrm{lt}+\mathrm{rl} \sigma^{2} \mathrm{t}$ \\
\hline L x T & $(1-1)(\mathrm{t}-1)$ & $\mathrm{M} 3$ & $\sigma^{2}+\mathrm{r} \sigma^{2} \mathrm{lt}$ \\
\hline Error & $(\mathrm{r}-1)(\mathrm{c}-1)$ & $\mathrm{M} 4$ & $\sigma^{2}$ \\
\hline
\end{tabular}

Where, c, r, 1 and $\mathrm{t}$ are the number of crosses, reps, lines and testers, respectively. Subscripts to the variance symbol designate the type of variance.

\section{RESULTS AND DISCUSSION}

\section{I.1. Mean squares (MS) for all studied traits along top crosses}

Highly significant mean square of crosses was observed for all the traits including days to $50 \%$ flowering, days to maturity, plant height, stalk diameter, head diameter, 100-achene weight, achene yield/plant, achene yield/plot and oil content, indicating significant variation for these traits (Table 2).

The mean squares due to lines were highly significant. While, variance amonge testers were highly significant only for plant hight, head diameter and oil content.

The significance of the line $\mathrm{x}$ tester interaction suggests that testers were able to discriminate within this set of inbred lines. Similar results were obtained by (Hussain et al. 1999, Khan et al. 2008, Bakheit et al. 2010, Syeda et al. 2011, Sayed 2012, Muhammad et al. 2012).

\section{I.2. Combining ability effects for testers, lines and their crosses}

Estimation of combining ability of new lines for identification of superior parents for hybridization is essential in sunflower breeding programs. General and Specific combining abilities as well as gene action for different agronomic traits have been estimated by many researchers Lines that have good mean performance in the first evaluation are advanced to a test involving tester and eventually to evaluate specific hybrid combinations (Fehr 1987).

Table (2) Mean squares (MS) for all studied traits along to top crosses.

\begin{tabular}{|c|c|c|c|c|c|c|c|c|c|c|}
\hline \multirow[b]{2}{*}{ S.O.V } & \multirow[b]{2}{*}{ d. $f$} & \multicolumn{9}{|c|}{ MS } \\
\hline & & $\begin{array}{c}\text { Days to } \\
50 \% \\
\text { flowering }\end{array}$ & $\begin{array}{l}\text { Days to } \\
\text { maturity }\end{array}$ & $\begin{array}{l}\text { Plant } \\
\text { height, } \\
\text { cm }\end{array}$ & $\begin{array}{c}\text { Stalk } \\
\text { diameter, } \\
\mathrm{cm}\end{array}$ & $\begin{array}{c}\text { Head } \\
\text { diameter, } \\
\mathrm{cm}\end{array}$ & $\begin{array}{l}100 \text {-achene } \\
\text { weight, } g\end{array}$ & $\begin{array}{c}\text { Achene } \\
\text { yield/plant, g }\end{array}$ & $\begin{array}{c}\text { Achene } \\
\text { yield/plot, } \\
\text { g }\end{array}$ & $\begin{array}{c}\text { Oil } \\
\text { content, } \\
\%\end{array}$ \\
\hline Rep. & 2 & 2.20 & 5.32 & 125.25 & 0.06 & 0.79 & 0.30 & 1.26 & 38.40 & 1.58 \\
\hline Crosses $(\mathrm{C})$ & 45 & $5.89 * *$ & $16.10 * *$ & $450.75^{* *}$ & $0.58 * *$ & $9.61 * *$ & $3.06^{* *}$ & $851.10^{* *}$ & $64492.25 * *$ & $12.93 * *$ \\
\hline Lines (L) & 22 & $9.32 * *$ & $23.15 * *$ & $669.10 * *$ & $0.60 * *$ & $6.88 * *$ & $3.28 * *$ & $935.94 * *$ & $72396.77 * *$ & $13.86^{* *}$ \\
\hline Testers $(\mathrm{T})$ & 1 & 6.09 & 2.09 & $3118.38 * *$ & 0.00 & $5.68 * *$ & 0.18 & 7.42 & 3099.39 & $62.67 * *$ \\
\hline $\mathrm{L} X \mathrm{~T}$ & 22 & 2.44 & 9.69 & $111.15^{* *}$ & $0.60 * *$ & $12.53 * *$ & $2.30 * *$ & $804.60 * *$ & $59378.32 * *$ & $9.74 * *$ \\
\hline Error & 90 & 1.89 & 1.67 & $16.36 * *$ & 0.10 & 0.67 & 0.24 & 16.37 & 1188.88 & 0.33 \\
\hline
\end{tabular}

$*, * *$ significant and highly significant at 0.05 and 0.01 levels of probability, respectively. 


\section{I.2.1. Days to $50 \%$ flowering}

Estimates of general and specific combining ability effects for days to $50 \%$ flowering are presented in Table (3).

The GCA effects of the 23 lines per se showed that fifteen S1 lines were negative effects, five S1 lines were negative and significant or highly significant GCA effects and considered as good combiners for earliness. While, six lines were positive and highly significant GCA effects. Otherwise, the testers showed insignificant GCA effects.

Table (3) Estimates of general effects for testers and lines and specific combining ability for crosses for days to $50 \%$ flowering, days to maturity and plant height.

\begin{tabular}{|c|c|c|c|c|c|c|c|c|c|}
\hline \multirow{4}{*}{$\begin{array}{l}\text { No. of } S_{1} \\
\quad \text { lines }\end{array}$} & \multicolumn{3}{|c|}{ Days to $50 \%$ flowering } & \multicolumn{3}{|c|}{ Days to maturity } & \multicolumn{3}{|c|}{ Plant height, $\mathrm{cm}$} \\
\hline & \multirow{3}{*}{ GCA } & \multirow{2}{*}{\multicolumn{2}{|c|}{$\frac{\text { SCA }}{\text { Tester }}$}} & \multirow{3}{*}{ GCA } & \multirow{2}{*}{\multicolumn{2}{|c|}{$\frac{\text { SCA }}{\text { Tester }}$}} & \multirow{3}{*}{ GCA } & \multirow{2}{*}{\multicolumn{2}{|c|}{$\frac{\text { SCA }}{\text { Tester }}$}} \\
\hline & & & & & & & & & \\
\hline & & $\mathrm{A}_{3}$ & $\mathrm{~A}_{21}$ & & $\mathrm{~A}_{3}$ & $\mathrm{~A}_{21}$ & & $\mathrm{~A}_{3}$ & $\mathrm{~A}_{21}$ \\
\hline 1 & $-2.54 * *$ & -0.88 & 0.88 & $-3.07 * *$ & -0.29 & 0.29 & $-17.91 * *$ & -1.92 & 1.92 \\
\hline 2 & -0.54 & -0.21 & 0.21 & $2.43 * *$ & 0.21 & -0.21 & $8.43 * *$ & 0.75 & -0.75 \\
\hline 3 & $-1.54 * *$ & -0.21 & 0.21 & $-3.57 * *$ & 0.21 & -0.21 & $8.74 * *$ & 3.58 & -3.58 \\
\hline 4 & $-1.38 *$ & -0.71 & 0.71 & $2.76^{* *}$ & 0.54 & -0.54 & $5.09 * *$ & -3.59 & 3.59 \\
\hline 5 & -0.04 & -0.04 & 0.04 & $-2.41 * *$ & 1.04 & -1.04 & $-12.91 * *$ & 0.08 & -0.08 \\
\hline 6 & $-1.38^{*}$ & 0.29 & -0.29 & $-2.91 * *$ & 0.21 & -0.21 & $-6.07 * *$ & -1.42 & 1.42 \\
\hline 7 & $1.62 * *$ & -0.71 & 0.71 & $-1.07 *$ & -0.62 & 0.62 & $-7.57 * *$ & -0.59 & 0.59 \\
\hline 8 & 0.46 & -0.54 & 0.54 & 0.43 & $2.88 * *$ & $-2.88^{* *}$ & $24.43 * *$ & $6.75^{*}$ & $-6.75^{*}$ \\
\hline 9 & 0.96 & -0.04 & 0.04 & 0.26 & -0.96 & 0.96 & -2.07 & 1.58 & -1.58 \\
\hline 10 & $-1.38^{*}$ & -0.04 & 0.04 & -0.24 & $1.88^{*}$ & $-1.88^{*}$ & -1.07 & $7.25 *$ & $-7.25^{*}$ \\
\hline 11 & -0.88 & -0.54 & 0.54 & 0.93 & 0.38 & -0.38 & 1.93 & $7.25 *$ & $-7.25^{*}$ \\
\hline 12 & -0.88 & 0.46 & -0.46 & -0.41 & 1.38 & -1.38 & $13.07 * *$ & -5.75 & 5.75 \\
\hline 13 & -0.04 & 0.29 & -0.29 & -0.57 & $1.88^{*}$ & $-1.88^{*}$ & $-4.91 * *$ & 1.75 & -1.75 \\
\hline 14 & $1.46^{* *}$ & 1.46 & -1.46 & $2.26^{* *}$ & 0.04 & -0.04 & $7.59 * *$ & 5.25 & -5.25 \\
\hline 15 & $1.62 * *$ & 0.62 & -0.62 & $1.76^{* *}$ & -2.79 & 2.79 & -0.74 & 2.58 & -2.58 \\
\hline 16 & -0.04 & 0.96 & -0.96 & 0.26 & -1.62 & 1.62 & $5.26 * *$ & -3.75 & 3.75 \\
\hline 17 & -0.21 & -0.21 & 0.21 & 0.43 & -1.46 & 1.46 & $-3.41 *$ & 0.58 & -0.58 \\
\hline 18 & $1.96^{* *}$ & -1.04 & 1.04 & 0.59 & -1.29 & 1.29 & $12.09 *$ & -1.25 & 1.25 \\
\hline 19 & -0.21 & 1.12 & -1.12 & $-2.24 * *$ & -0.79 & 0.79 & 1.93 & $-9.09 * *$ & $9.09 * *$ \\
\hline 20 & $1.79 * *$ & 0.46 & -0.46 & $2.59 * *$ & 0.04 & -0.04 & $16.26^{* *}$ & -4.75 & 4.75 \\
\hline 21 & -0.04 & -0.04 & 0.04 & $-1.91 * *$ & -0.12 & 0.12 & $16.57 * *$ & -1.25 & 1.25 \\
\hline 22 & $1.46^{* *}$ & -0.21 & 0.21 & $2.59 * *$ & -0.62 & 0.62 & $10.43 * *$ & -5.25 & 5.25 \\
\hline 23 & -0.21 & -0.21 & 0.21 & $1.09 *$ & -0.12 & 0.12 & 1.59 & 1.25 & -1.25 \\
\hline GCA & & 0.21 & -0.21 & & 0.12 & -0.12 & & $4.75 * *$ & $-4.75 * *$ \\
\hline S.E (gi.) & & 0.56 & & & 0.53 & & & 1.65 & \\
\hline S.E (g.j) & & 0.17 & & & 0.16 & & & 0.49 & \\
\hline S.E (Sij) & & 0.79 & & & 0.75 & & & 2.34 & \\
\hline
\end{tabular}

*** significant and highly significant at 0.05 and 0.01 levels of probability, respectively. 
On the other hand, SCA effects of the crosses presented in Table (3) showed that out of 46 F1 crosses, 23 crosses exhibited insignificant and negative SCA effects. While 23 crosses exhibited insignificant and positive SCA effects. Generally, the earliest crosses could be expected from crossing testers with the lines which having negative GCA effects. While the later flowering crosses had positive SCA effects.

\section{I.2.2. Days to maturity}

Estimates of GCA and SCA effects of days to maturity for testers and $\mathrm{S}_{1}$ lines per se along with crosses are presented in Table (3).

The results indicated that ten $\mathrm{S} 1$ lines were the earliest maturing lines. Seven lines showed negative significant or highly significant GCA effects. While, seven lines showed positive and significant or highly significant GCA effects. Whereas, the testers showed insignificant GCA effects. These results reflect that these lines could be considered as good combiner to improve days to maturity.

Concerning, of SCA effects (Table 3), the results indicate that 3 crosses exhibited negative and significant. This indicates that these crosses could be considered as best combination for days to maturity. On the other hand, three crosses possessed positive and significant SCA effects. In general, these results showed that to obtain crosses having SCA effects, at least one of the parents should have high GCA ratio.

\section{I.2.3. Plant height, $\mathrm{cm}$}

Estimates of GCA and SCA effects of plant height for the testers and lines along with their crosses are shown in Table (3).

Six lines showed significantly or highly significantly negative GCA effects. Moreover, three lines showed insignificantly negative GCA. Consequently, these lines could be used as a parent for this trait. While, eleven lines showed significantly or highly significantly positive GCA effects. On the other side, the testers were highly significant GCA effects. Significant negative GCA effects were detected for plant height and lifeduration (Khan et al. 2008; Ghaffari et al. 2011).

Results concerning the SCA values for the crosses (Table 3), indicated that eight crosses were significantly or highly significantly SCA effects. Only four crosses exhibited negatively significant SCA effects. These results reflected that these crosses had desirable gene action for shortness. While the highest positive SCA effect was registered for the tallest cross $\left(\mathrm{S}_{19} \times \mathrm{A}_{21}\right)$.

\section{I.2.4. Stalk diameter, $\mathrm{cm}$}

Estimates of GCA and SCA values of the stalk diameter for the lines and testers along with their crosses are presented in Table (4).

The GCA effects for stalk diameter of lines were highly significant and positive for seven lines. These lines were considered the best combiners for thick stem. While seven lines showed the highest negatively and significantly GCA effects. On the other hand, the testers GCA effects equal zero.

Concerning the SCA values for the crosses showed that twenty four crosses were significantly or highly significantly SCA effects. Only twelve crosses exhibited positive significant or highly significant SCA effects. These crosses were considered as good combinations for this trait.

\section{I.2.5. Head diameter, $\mathrm{cm}$}

Estimates of GCA and SCA values for the lines and testers along with their crosses are showed in Table (4).

Results indicated that eleven lines had positive GCA effects. Seven out of them gave highly significant positive GCA effect. This results indicates that these lines could be considered as good combiners and having favorable genes for increasing head diameter. While five lines were showed highly significant and negative GCA effects. On the other hand, the GCA effects for testers displayed significant. 
Results of SCA effects of crosses (Table 4), showed that twelve crosses had positive and significant or highly significant SCA effects. Therefore, these combinations can be good candidate for head diameter improving. On the contrary, twelve crosses showed negative and significant or highly significant SCA effects.

Table (4) Estimates of general effects for testers and lines and specific combining ability for crosses for stalk diameter, head diameter and 100-achene weight.

\begin{tabular}{|c|c|c|c|c|c|c|c|c|c|}
\hline \multirow{4}{*}{$\begin{array}{l}\text { No. of } \\
\mathrm{S}_{1} \text { lines }\end{array}$} & \multicolumn{3}{|c|}{ Stalk diameter, cm } & \multicolumn{3}{|c|}{ Head diameter, $\mathrm{cm}$} & \multicolumn{3}{|c|}{ 100-achene weight, $g$} \\
\hline & \multirow{3}{*}{ GCA } & \multirow{2}{*}{\multicolumn{2}{|c|}{$\frac{\text { SCA }}{\text { Tester }}$}} & \multirow{3}{*}{ GCA } & \multirow{2}{*}{\multicolumn{2}{|c|}{$\frac{\text { SCA }}{\text { Tester }}$}} & \multirow{3}{*}{ GCA } & \multirow{2}{*}{\multicolumn{2}{|c|}{$\frac{\text { SCA }}{\text { Tester }}$}} \\
\hline & & & & & & & & & \\
\hline & & $\mathrm{A}_{3}$ & $\mathrm{~A}_{21}$ & & $A_{3}$ & $\mathrm{~A}_{21}$ & & $\mathrm{~A}_{3}$ & $\mathrm{~A}_{21}$ \\
\hline 1 & $-0.55^{* *}$ & 0.00 & 0.00 & $1.09 * *$ & $1.37 * *$ & $-1.37 * *$ & $0.93^{* *}$ & 0.30 & -0.30 \\
\hline 2 & $0.45 * *$ & 0.00 & 0.00 & $1.09^{* *}$ & $2.04 * *$ & $-2.04 * *$ & 0.27 & 0.30 & -0.30 \\
\hline 3 & $-0.38 * *$ & 0.17 & -0.17 & $-0.91 * *$ & -0.30 & 0.30 & $-0.40 *$ & 0.30 & -0.30 \\
\hline 4 & 0.12 & $-0.33^{*}$ & $0.33^{*}$ & $-1.41^{* *}$ & $-1.13^{*}$ & $1.13^{*}$ & $-0.90 * *$ & $-1.20 * *$ & $1.20 * *$ \\
\hline 5 & -0.05 & $0.50^{* *}$ & $-0.50 * *$ & $1.59 * *$ & $3.54 * *$ & $-3.54 * *$ & -0.23 & 0.13 & -0.13 \\
\hline 6 & $-0.55^{* *}$ & 0.00 & 0.00 & $1.09 * *$ & 0.70 & -0.70 & $-1.40 * *$ & 0.30 & -0.30 \\
\hline 7 & $0.28 * *$ & 0.17 & -0.17 & -0.24 & -0.30 & 0.30 & $0.77 * *$ & 0.46 & -0.47 \\
\hline 8 & $0.28 * *$ & 0.17 & -0.17 & 0.09 & -0.63 & 0.63 & $0.77 * *$ & $1.13 * *$ & $-1.13^{* *}$ \\
\hline 9 & $-0.55^{* *}$ & 0.00 & 0.00 & $-1.74 * *$ & -0.46 & 0.46 & -0.07 & $-1.04 * *$ & $1.04 * *$ \\
\hline 10 & -0.05 & $0.50^{* *}$ & $-0.50^{* *}$ & -0.24 & $-1.30 * *$ & $1.30 * *$ & 0.10 & $-0.87 * *$ & $0.87 * *$ \\
\hline 11 & $0.28 * *$ & -0.17 & 0.17 & 0.59 & $1.87 * *$ & $-1.87 * *$ & $0.43^{*}$ & $1.46^{* *}$ & $-1.46^{* *}$ \\
\hline 12 & 0.12 & $0.33^{*}$ & $-0.33 *$ & $-1.74 * *$ & 0.20 & -0.20 & 0.27 & -0.04 & 0.04 \\
\hline 13 & -0.05 & $-0.50 * *$ & $0.50 * *$ & -0.41 & $2.20 * *$ & $-2.20 * *$ & $-0.40^{*}$ & -0.04 & 0.04 \\
\hline 14 & $0.45 * *$ & 0.00 & 0.00 & $2.09 * *$ & 0.70 & -0.70 & $1.43 * *$ & 0.46 & -0.46 \\
\hline 15 & 0.12 & $0.33^{*}$ & $-0.33 *$ & $-0.57^{*}$ & $-0.96^{*}$ & $0.96^{*}$ & $-0.90 * *$ & -0.54 & 0.54 \\
\hline 16 & $0.28 * *$ & -0.17 & 0.17 & -0.41 & -0.13 & 0.13 & 0.10 & 0.13 & -0.13 \\
\hline 17 & $-0.22 *$ & $0.33^{*}$ & $-0.33 *$ & $-1.24 * *$ & $-0.96^{*}$ & $0.96^{*}$ & $-0.73 * *$ & $0.63^{*}$ & $-0.63^{*}$ \\
\hline 18 & -0.05 & $-0.50 * *$ & $0.50 * *$ & 0.09 & $-1.96 * *$ & $1.96 * *$ & -0.23 & $-1.20 * *$ & $1.20 * *$ \\
\hline 19 & $-0.22 *$ & $-0.33^{*}$ & $0.33^{*}$ & $-0.74 *$ & -0.46 & 0.46 & $-1.23^{* *}$ & -0.20 & 0.20 \\
\hline 20 & -0.05 & $-0.50 * *$ & $0.50 * *$ & -0.41 & $-1.46^{* *}$ & $1.46^{* *}$ & $0.93 * *$ & $-0.70 *$ & $0.70^{*}$ \\
\hline 21 & $-0.22 *$ & $0.33^{*}$ & $-0.33^{*}$ & 0.09 & -0.30 & 0.30 & -0.23 & 0.13 & -0.13 \\
\hline 22 & 0.12 & $-0.33^{*}$ & $0.33^{*}$ & $0.93^{* *}$ & $-2.46^{* *}$ & $2.46^{* *}$ & $0.77 * *$ & -0.54 & 0.54 \\
\hline 23 & $0.45^{* *}$ & 0.00 & 0.00 & $1.26^{* *}$ & 0.20 & -0.20 & -0.07 & $0.63^{*}$ & $-0.63 *$ \\
\hline GCA & & 0.00 & 0.00 & & $-0.20^{*}$ & $0.20^{*}$ & & 0.04 & -0.04 \\
\hline S.E (gi.) & & 0.11 & & & 0.33 & & & 0.20 & \\
\hline S.E (g.j) & & 0.03 & & & 0.10 & & & 0.06 & \\
\hline S.E $(\mathrm{Sij})$ & & 0.15 & & & 0.47 & & & 0.28 & \\
\hline
\end{tabular}

*** significant and highly significant at 0.05 and 0.01 levels of probability, respectively. 


\section{I.2.6. 100-achene weight, $g$}

Estimates of general and specific combining ability effects for the lines, testers and their crosses for 100-achene weight are presented in Table (4).

Data of GCA effects of lines indicated that eleven lines were positive GCA effects. One and six lines had positive significant and highly significant GCA effects, respectively.

These lines were considered as a good combiner for 100-achene weight. While, five lines exhibited negative and highly significant GCA effects. On the other hand, the testers were showed not significant GCA effects.

Concerning, the SCA effects nine crosses exhibited positive and significant or highly significant SCA effects (Table 4).

However, nine crosses registered significantly and negative SCA effects. While, nine crosses exhibited significant and positive values. Moreover, most of the heaviest hybrids in 100achene weight results from crossing lines having positive and significant GCA values. It may be concluded that GCA and SCA effects, were effective in predicting hybrids performance in 100achene weight.

\section{I.2.7. Achene yield/plant, g}

Estimates of GCA and SCA effects of the achene yield/plant for the testers and lines along with their crosses are presented in Table (5).

The GCA effects of ten lines were positive and highly significant, while eleven lines showed negative and highly significant GCA effects. These lines considered as a good combiner for achene yield/plant. Whereas, the GCA effects of the testers exhibited insignificant.

Result of SCA effects (Table 5) of crosses indicated that eighteen crosses showed positive and significant or highly significant SCA effects. Reflecting that these crosses could be considered the best combination for this trait. However, eighteen crosses registered negative and significant or highly significant SCA effects.

It is worthy to mention that most of the heaviest crosses in achene yield/plant derived from crossing lines having positive and significant GCA effects.

\section{I.2.8. Achene yield/plot, g}

Estimates of general and specific combining ability effects of the achene yield/plot for the testers and lines along with their crosses are listed in Table (5).

The GCA effects of the lines were positive and highly significant for ten lines. While the negative and highly significant effects were recorded for eleven lines. This result indicates that these lines had desirable gene action and could be considered as good combiners for increasing the achene yield/plot. Whereas, the GCA effects of the testers were insignificant.

Respect to specific combining ability, results showed that eighteen crosses were registered positive and significant or highly significant SCA effects, and were suitable combinations for this trait. Whereas, eighteen crosses recorded negative and significant or highly significant SCA effects.

It is of interest of indicate the GCA effects assessed the contribution of each genotype to it progeny response positive values indicate a contribution toward a large effect on achene yield/plot. While negative values indicate a contribution toward smaller effects.

\section{I.2.9. Oil content, \%}

Estimates of GCA and SCA effects of the lines, testers and their crosses for oil content are listed in Table (5).

The results showed that ten $\mathrm{S} 1$ lines $\left(\mathrm{S}_{1}, \mathrm{~S}_{3}, \mathrm{~S}_{5}\right.$, $\mathrm{S}_{7}, \mathrm{~S}_{8}, \mathrm{~S}_{11}, \mathrm{~S}_{13}, \mathrm{~S}_{15}, \mathrm{~S}_{17}$ and $\mathrm{S}_{23}$ ) exhibited positive GCA effects. Nine lines out of ten, were significant or highly significant GCA effects. These lines should be considered as good combiners for oil content, and its implies that these lines possess 
favorable alleles with additive genetic effects for this trait.

The same result was found by the analysis of half-sib families. Whereas, that the respective S1 lines would have good g.c.a for oil content and selected as parent to produce the first cycle of recurrent selection for the population H.S.

However, thirteen lines showed negative GCA effects. Eleven out of them had significant or highly significant GCA effects. The testers GCA values exhibited non-significant.

Table (5) Estimates of general effects for testers and lines and specific combining ability for crosses for achene yield/plant, achene yield/plot and oil content.

\begin{tabular}{|c|c|c|c|c|c|c|c|c|c|}
\hline \multirow{4}{*}{$\begin{array}{c}\text { No. of } S_{1} \\
\text { lines }\end{array}$} & \multicolumn{3}{|c|}{ Achene yield/plant, g } & \multicolumn{3}{|c|}{ Achene yield/plot, g } & \multicolumn{3}{|c|}{ Oil content, \% } \\
\hline & \multirow{3}{*}{ GCA } & \multirow{2}{*}{\multicolumn{2}{|c|}{$\frac{\mathrm{SCA}}{\text { Tester }}$}} & \multirow{3}{*}{ GCA } & \multirow{2}{*}{\multicolumn{2}{|c|}{$\frac{\mathrm{SCA}}{\text { Tester }}$}} & \multirow{3}{*}{ GCA } & \multirow{2}{*}{\multicolumn{2}{|c|}{$\frac{\text { SCA }}{\text { Tester }}$}} \\
\hline & & & & & & & & & \\
\hline & & $\mathrm{A}_{3}$ & $\mathrm{~A}_{21}$ & & $\mathrm{~A}_{3}$ & $\mathrm{~A}_{21}$ & & $\mathrm{~A}_{3}$ & $\mathrm{~A}_{21}$ \\
\hline 1 & $13.99 * *$ & $7.57 * *$ & $-7.57 * *$ & $137.33^{* *}$ & $60.24 * *$ & $-60.24 * *$ & 0.14 & $-1.33^{* *}$ & $1.33 * *$ \\
\hline 2 & $7.49 * *$ & $5.07 *$ & $-5.07 *$ & $62.83^{* *}$ & $49.07 *$ & $-49.07 *$ & -0.20 & -0.33 & 0.33 \\
\hline 3 & $-20.35^{* *}$ & $13.57 * *$ & $-13.57 * *$ & $-184.01^{* *}$ & $122.57^{* *}$ & $-122.57^{* *}$ & $1.80 * *$ & $1.34^{* *}$ & $-1.34 * *$ \\
\hline 4 & $-13.85^{* *}$ & $-8.93^{* *}$ & $8.93 * *$ & $-121.67^{* *}$ & $-72.76^{* *}$ & $72.76^{* *}$ & -0.36 & $1.17 * *$ & $-1.17 * *$ \\
\hline 5 & $-6.51 * *$ & 3.07 & -3.07 & $-63.84 * *$ & 26.76 & -26.76 & $1.97 * *$ & $-1.49^{* *}$ & $1.49^{* *}$ \\
\hline 6 & $-24.51 * *$ & 0.07 & -0.07 & $-224.67 * *$ & -2.43 & 2.43 & $-0.86^{* *}$ & 0.01 & -0.01 \\
\hline 7 & $6.82 * *$ & $-6.27 * *$ & $6.27 * *$ & $51.83^{* *}$ & $-49.93 *$ & $49.93 *$ & $0.97 * *$ & $-0.49 * *$ & $0.49 * *$ \\
\hline 8 & -2.35 & $26.23 * *$ & $-26.23 * *$ & -7.84 & $224.74 * *$ & $-224.74 * *$ & $0.47^{*}$ & $2.34 * *$ & $-2.34 * *$ \\
\hline 9 & 0.65 & $-13.77 * *$ & $13.77 * *$ & 5.49 & $-121.26 * *$ & $121.26^{* *}$ & $-1.53 * *$ & 0.01 & -0.01 \\
\hline 10 & $7.49 * *$ & $-15.93 * *$ & $15.93 * *$ & $66.66^{* *}$ & $-137.09 * *$ & $137.09^{* *}$ & $-1.86^{* *}$ & -0.33 & 0.33 \\
\hline 11 & $11.32 * *$ & $11.57 * *$ & $-11.57 * *$ & $95.83 * *$ & $111.07 * *$ & $-111.07 * *$ & $1.64 * *$ & 0.51 & 0.51 \\
\hline 12 & $-5.51 * *$ & 3.40 & -3.40 & $-47.67 * *$ & $39.24 *$ & $-39.24 *$ & $-0.53 *$ & -0.33 & 0.33 \\
\hline 13 & $-5.35 * *$ & -2.10 & 2.10 & $-41.34 * *$ & -31.76 & 31.76 & $2.47 * *$ & 0.34 & -0.34 \\
\hline 14 & $17.82 * *$ & $-11.93 * *$ & $11.93 * *$ & $157.33 * *$ & $-100.09 * *$ & $100.09 * *$ & $-0.53 *$ & $-0.99 * *$ & $0.99 * *$ \\
\hline 15 & $-14.85 * *$ & $-9.27 * *$ & $9.27 * *$ & $-124.17^{* *}$ & $-77.93 * *$ & $77.93 * *$ & $2.97 * *$ & $-1.83 * *$ & $1.83 * *$ \\
\hline 16 & $8.32 * *$ & $8.57 * *$ & $-8.57 * *$ & $71.49 * *$ & $64.07 * *$ & $-64.07 * *$ & $-1.53 * *$ & 0.34 & -0.34 \\
\hline 17 & $-11.35 * *$ & $13.90 * *$ & $-13.90 * *$ & $-90.84 * *$ & $114.72 * *$ & $-114.72 * *$ & $0.80 * *$ & $2.34 * *$ & $-2.34 * *$ \\
\hline 18 & $-4.85 * *$ & $-19.60 * *$ & $19.60 * *$ & $-53.51 * *$ & $-170.26^{* *}$ & $170.26^{* *}$ & $-1.36^{* *}$ & $-0.83^{*}$ & $0.83^{*}$ \\
\hline 19 & $-5.51 * *$ & $-8.93 * *$ & $8.93 * *$ & $-42.17 * *$ & $-69.26^{* *}$ & $69.26^{* *}$ & $-3.03 * *$ & 0.17 & -0.17 \\
\hline 20 & $15.32 * *$ & $-5.10^{*}$ & $5.10^{*}$ & $138.49 * *$ & $-43.59 *$ & $43.59 *$ & $-0.86^{* *}$ & $1.34 *$ & $-1.34 * *$ \\
\hline 21 & $-6.68 * *$ & -2.10 & 2.10 & $-52.17 * *$ & -30.93 & 30.93 & $-0.70 * *$ & 0.17 & -0.17 \\
\hline 22 & $20.65^{* *}$ & $-5.10^{*}$ & $5.10^{*}$ & $174.66^{* *}$ & -38.43 & 38.42 & $-1.03 * *$ & $0.84 *$ & $*_{-0.84}$ \\
\hline 23 & $11.82 * *$ & $16.07 * *$ & $-16.07 * *$ & $91.99 * *$ & $133.91^{* *}$ & $-133.91 * *$ & $1.14 * *$ & $-2.99 * *$ & $2.99 * *$ \\
\hline GCA & & -0.23 & 0.23 & & -4.74 & 4.74 & & -0.67 & 0.67 \\
\hline S.E (gi.) & & 1.65 & & & 14.08 & & & 0.23 & \\
\hline S.E (g.j) & & 0.49 & & & 4.15 & & & 0.07 & \\
\hline S.E (Sij) & & 2.34 & & & 19.91 & & & 0.33 & \\
\hline
\end{tabular}

*** significant and highly significant at 0.05 and 0.01 levels of probability, respectively. 
Concerning the SCA values for oil content, the results indicated that thirteen crosses were positive and significant or highly significant. These crosses were suitable combination and can be superior candidate for improving high oil content genotypes.

Therefore, we are selected the best 10 crosses exhibited positive significant or highly significant, $\left(S_{1} \times A_{21}, \quad S_{3} \times A_{3}, \quad S_{4} \times A_{3}, \quad S_{5} \times A_{21}, \quad S_{8} \times A_{3}\right.$, $S_{14} \times A_{21}, S_{15} \times A_{21}, S_{17} \times A_{3}, S_{20} \times A_{3}$ and $S_{23} \times$ $A_{21}$ ) as parents to produce the first cycle of recurrent selection for population top crosses. In earlier studies (Khan et al. 2009; Karasu et al. 2010) were reported significant SCA effects for oil content, seed yield and yield associated traits.

Soheila et al. (2013) found that crosses of RGK$21 \times$ AGK-52, RGK-19 $\times$ AGK-52 and RGK-21 $\times$ AGK-148 were identified with desired specific combining ability (SCA) for grain and oil yield. It is concluded that selection for achieving high grain yield must be done for grain/head and 1000-kernel weight.

Godfree et al. (2014) showed predominance of $\sigma^{2}$ gca over $\sigma^{2}$ sca for seed yield and oil yield indicating that superior TCHs can be identified based on positive and significant GCA effects of the female lines. For oil content $\sigma^{2}$ sca was predominant over $\sigma^{2}$ gca indicating that selecting for TCHs with high oil content would be best among line $\times$ tester combinations and not among female $\mathrm{S}_{3} \mathrm{CMS}$ lines per se.

\section{REFERENCE}

A. O. A. C., (1980). Association of Dfficial Agricultural Chemists. Official and Tentative Methods of Analysis of the Association Agricultural. Chemists $6^{\text {th }}$ ed., Washington, DC, USA.

Bakheit B. R., El-Shimy A. A., Mahmoud A. M. and Attia M. A., (2010). Heterosis for yield and its components in sunflower. Egypt. Journal of Plant Breed, 14 (1): 159-172.
Bajaj R. K., Aujla K. K. and Chahal G. S., (1997). Combining ability studies in sunflower (Helianthus annuus L.). Crop improve, 34: 141-146.

F. A. O., (2011). Food and Agriculture Organization of the United Nation, www.FAO@IC.F. Computer Research.

Fehr W. R., (1987). Principles of Cultivar Development. 1: Theory and Technique. Macmillan Publishing Company Inc. New York.

El-Hity M. A., (1992). Genetical analysis of some agronomic characters in sunflower. Pp 11181128. in: Proceedings of the 13. International Sunflower Conference, Italy.

Ghaffari M., Farrokhi I. and Mirzapour M., (2011). Combining ability and gen action for agronomic traits and oil content in sunflower (Helianthus annuus L.) using $\mathrm{F}_{1}$ hybrids. Crop Breed. J, 1 (1):75-87.

Godfree, C. K., Mashingaidze and Shanahan P., (2014). Advanced cycle pedigree breeding in sunflower. II: combining ability for oil yield and its components. Euphytica, 195 (2): 183195.

Hladni N., Skoric D., Kraljevic-Balalic M., Sakacand Z. and Jovanovic D., (2006). Combining ability for oil content and its correlations with other yield components in sunflower (Helianthus annuus L.). Helia, 29 (44): 101-110.

Hussain T., Pooni H. S., Phillimon-Banda M. H. and Toms E. M., (1999). The nature of quantitative variation in a large set of early maturing sunflower test crosses. Journal of Agricultural Science, 133(2): 175-184.

Karasu A., Oz M., Sincik M., Turan Z. M. and Gokosoy A. T., (2010). Combining Ability and Heterosis for Yield and Yield Component in sunflower. Not. Bot. Hort. Notulae Botanicae Horti Agrobotanici Cluj-Napoca38 (3): 259-264. 
Kempthorne O., (1957). Yield stability of single, three ways and double crosses hybrids. Sorghum News Letter, 33:59.

Khan S. A., Khan A., Saeed M. and Khan S. M., (2009). Using line $\mathrm{x}$ tester analysis for earliness and plant height traits in sunflower (Helianthus annuus L.). Recent Research in Science and Technology 1 (5): 202-206.

Khan S. A., Qureshi A. S., Muhammad A., Khan S. M., Saifullah A. and Khalil I. H., (2008). Estimates of heterosis for seed yield and oil contents in sunflower (Helianthus annuus L.). Sarhad Journal of Agriculture, 24(1): 43-48.

Mahmoud A. M. (2012). Genetic Variability in S4 Inbred Lines of Sunflower under Sandy Soil Conditions. American-Eurasian Journal of Agriculture \& Environmental Science, 12 (3): 282-286.

Muhammad W. A., Muhammad S. A. and Hammad N. T., (2012). Combining ability analysis for achene yield and related traits in sunflower (Helianthus annuus L.). Chilean Journal of Agricultural Research, 72(1): 2126.
Sayed A. A., Norof M. and Valiollah R., (2012). Combining ability of agronomic traits in sunflower (Helianthus annuus L.) using line $\mathrm{x}$ tester analysis. International Journal of Biology, 4(1):89-95.

Singh R. K. and Chaudhary B. D., (1977). Line x Tester Analysis. In Biometrical Methods in Quantitative Genetic Analysis P. 178-185 Kalyani publication, New Delhi.

Singh R. K. and Chaudhary B. D., (2001). Biometrical Techniques in Breeding and Genetic. 350 pp. Saujanya Books. Delhi.

Soheila A., Eivazi A. R.., Saba J. and Niazkhani M., (2013). Genetic analysis inbred lines and hybrids of sunflower (Helianthus annuus L.). Peak Journal of Agricultural Sciences, 1 (3): 48-53.

Syeda N., Fatima Z., Ishaque M., Mohamand A. S., Khan M., Khan R. and Chaudhary M. F., (2011). Heritability analysis for seed yield and yield related components in sunflower (Helianthus annuus L.) based on genetic difference. Pakistan Journal of Botany, 43(2): 1295-1306. 
القدرة على الائلاف للصفات المحصولية فى عباد الشمس من خلال تحليل السلالة × الكثاف محروس عبد الباسط عطيه'، باهى راغب بخيت`، عاطف ابوالوفا احمدَوعابدين احمد الثيمى'

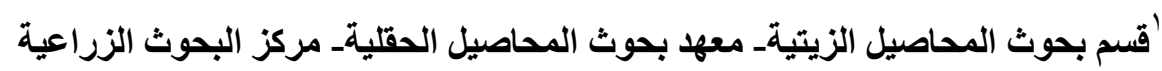

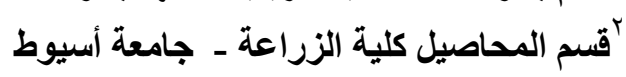

المخلص

تم انتاج ستة وأربعون هجين قمى من عباد الثمس فى موسم • . . ب بمحطة البحوث الزراعية بثندويل, وذلك من خلال التهجين بين ثلاثة وعشرون عائلة ملقحة ذاتيا وكثافين. فى موسم / 1 ــ تم تقييم الهجن القمية مـع الكثـافين فى تصميم القطاعات الكاملة العثوائية من ثلاثة مكررات. أوضح تحليل التباين أن متوسط مربعات الانحرافات للهجن كانت عالية المعنويـة لكل الصفات المدروسة والتتى شملت صفات عدد الأيام من الزراعة حتى • ٪\% تزهير، عدد الأيام من الزراعة حتى النضـج، طول النبات، قطر النبات، قطر القرص، وزن ال . . 1 بذرة، محصول النبات الفردى، محصول القطعة التجريبية ونسبة الزيت فى البذور. أيضا كان متوسط مربعات الانحرافات للسـلالات كان معنوى جدا لكل الصفات المدروسـة. بينما كان التباين عاليا بين الكشافين فقط فى صفات طول النبات، قطر القرص ونسبة الزيت فى البذور . بالنسبة لتاثير القدرة على الائتلاف لصفة نسبة الزيت في البذور كان هناك عشرة عائلات أظهرت قدرة عامـة موجبة. تسعة منها كانت ذات تأثير معنوى هى ( (، ب، ه، ^،

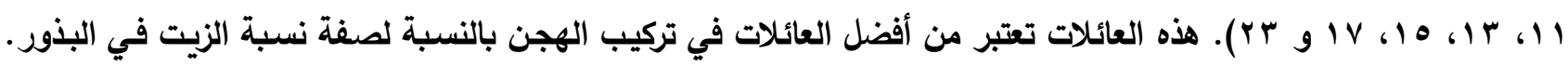

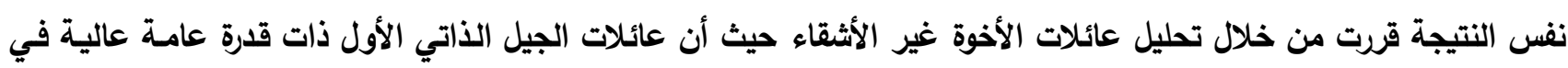
نسبة الزيت في البذور وتم انتخابها كآباء للحصول على الدورة الأولى من الانتخاب الدورى لعشيرة الإخوة غير الأثقاء. أمـا فيما يتعلق بتأثيرات القدرة الخاصة كان هناك ثلاثة عشر هجينا ذات قدرة موجبة ومعنوية أو عالية المعنوية. وتم انتخاب أحسن $S_{1} \times A_{21}, S_{3} \times A_{3}, S_{4} \times A_{3}, S_{5} \times A_{21}, S_{8} \times A_{3}, S_{14} \times A_{21}, S_{15} \times A_{21}, S_{17} \times A_{3}, S_{20} \times$ (شرة هجن A A $_{3}$ 